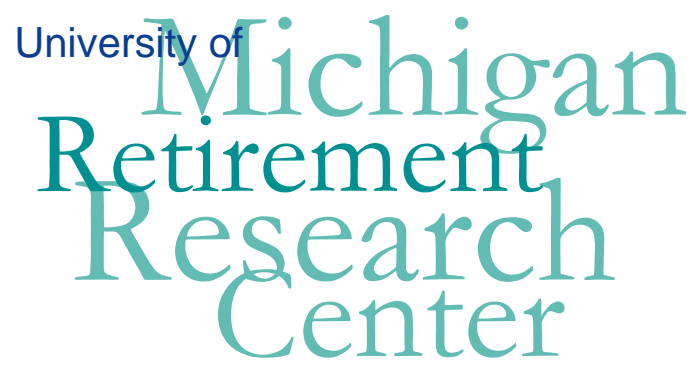

Working Paper

WP 2004-086

The Impact of Health Status and Out-of-Pocket Medical Expenditures on Annuity Valuation

Cassio M. Turra and Olivia S. Mitchell

\begin{tabular}{|l|l|l|}
\hline $\mathrm{M}$ & $\mathrm{R}$ \\
\hline $\mathrm{R}$ & $\mathrm{C}$ & \\
\hline
\end{tabular}$\quad$ Project \#: UM04-03 


\title{
The Impact of Health Status and Out-of-Pocket Medical Expenditures on Annuity Valuation
}

\author{
Cassio M. Turra \\ University of Pennsylvania \\ Olivia S. Mitchell \\ University of Pennsylvania
}

\author{
July 2004 \\ Michigan Retirement Research Center \\ University of Michigan \\ P.O. Box 1248 \\ Ann Arbor, MI 48104
}

\section{Acknowledgements}

This work was supported by a grant from the Social Security Administration through the Michigan Retirement Research Center (Grant \# 10-P96362-5). The opinions and conclusions are solely those of the authors and should not be considered as representing the opinions or policy of the Social Security Administration or any agency of the Federal Government.

\section{Regents of the University of Michigan}

David A. Brandon, Ann Arbor; Laurence B. Deitch, Bingham Farms; Olivia P. Maynard, Goodrich; Rebecca McGowan, Ann Arbor; Andrea Fischer Newman, Ann Arbor; Andrew C. Richner, Grosse Pointe Park; S. Martin Taylor, Gross Pointe Farms; Katherine E. White, Ann Arbor; Mary Sue Coleman, ex officio 


\title{
The Impact of Health Status and Out-of-Pocket Medical Expenditures on Annuity Valuation
}

\author{
Cassio M. Turra \\ Olivia S. Mitchell
}

\begin{abstract}
This paper describes how differences in health status at retirement can influence the decision to purchase a life annuity. We extend previous research on annuitization decisions by incorporating the effect of health differentials via differences in survival throughout the latter portion of life. Next, we consider how precautionary savings motivated by uncertain out-of-pocket medical expenses influence annuitization decisions. Our results show that annuities become less attractive to people facing uncertain medical expenses. While full annuitization would still be optimal if annuity markets were truly complete and both life- and health-contingent, lacking this, annuity equivalent wealth values are much lower for those in poor health, as compared to persons in good health.
\end{abstract}

\section{Authors' Acknowledgement}

This research was conduct with support from the Social Security Administration via the Michigan Retirement Research Center at the University of Michigan and the Pension Research Council at the Wharton School of the University of Pennsylvania. Additional support was provided to the first author by Grant AG10168 from the National Institute on Aging, Samuel H. Preston, Principal Investigator. Useful comments were provided by Irma Elo, Silvia Matos, Alex Muermann, Samuel Preston, Sara Rix, and members of the Wharton IRM Study Group. We are especially grateful to Jeffrey Brown for sharing his optimization code and for his many useful suggestions. Any errors are the authors' responsibility. (C2004 by Turra and Mitchell. All rights reserved. 


\section{The Impact of Health Status and Out-of-Pocket Medical Expenditures on Annuity Valuation}

Cassio M. Turra and Olivia S. Mitchell

The primary purpose of annuities is to protect people against the risk of outliving their own financial resources in old age. Prior research has shown that annuities should be of substantial value to risk-averse people who face an uncertain date of death (Yaari 1965), yet relatively few people seem to purchase annuities at the point of retirement (Johnson, Burman, and Kobes 2004). A growing body of research has focused on the factors that may explain this puzzle, factors that include a desire to leave bequests, the existence of adverse selection in the annuity market, the over-annuitization of retirement wealth, and the need for liquidity. Further, researchers have found that people use private information about their survival chances to make the decision of purchasing an annuity, and those who anticipate living longer are more likely to buy an annuity (Petrova 2003).Yet currently we have a poor understanding of how private information on health status is related to the demand for annuities. Investigations of this kind are challenging for a number of reasons, including the multi-dimensional aspect of health, and the absence of long-term nationally representative panel data on health at older ages.

The objective of this paper is to address this gap in knowledge by describing how differences in health status at retirement can influence the decision to purchase a life annuity. To do this, we use dynamic discrete choice estimation which is based on standard models of economic behavior. We propose two models which incorporate the effect of health differentials on annuitization valuation. One approach incorporates the effect of health via differences in survival throughout the life-cycle. However this approach does not consider precautionary savings motivated by uncertain out-of-pocket medical expenses, so in an extension, retirees in 
different health states are posited to consider both the effects of uncertain out-of-pocket medical expenses and uncertain survival, when making choices about annuitization. We compare the optimal level of annuitization and the insurance value of a life annuity for people in different health states at the point of annuity purchase.

As compared to previous studies, this paper is distinguished by its effort to measure the impact of anticipated poor health on annuity valuation. This is important in the retirement context since there is substantial risk of becoming disabled after age 65: at age 70, for instance, people must anticipate that they will have severe functional limitations for about one-quarter of their remaining lifetimes. Further, 70 percent of their remaining years will be spent with at least some functional difficulty (Crimmins, Hayward, and Saito 1994). In addition, greater disability implies much higher spending for the elderly: people with severe functioning limitations have annual Medicare costs $\$ 7,000$ higher than nondisabled persons (Cutler and Meara 2001). Therefore our study is informative regarding the potential for development of an impaired annuity market that offers higher payouts for consumers in poor health.

Understanding how health status affects annuity markets is also important for policy analysts, in particular those who propose personal Social Security retirement accounts (Cogan and Mitchell 2003). Recent research has suggested that mandating annuitization for all participants in a personal accounts scheme would imply transfers from high-mortality risk groups to low-mortality risk groups (c.f. Brown 2003). Health and mortality are also strongly associated, particularly among the elderly (Hurd, McFadden, and Merrill 2001). Consequently, understanding how health influences the insurance value of annuities may help insurers fashion annuity offerings under Social Security reform plans, so as to make a larger proportion of the participants better off. 


\section{Background}

Over the last three decades, defined contribution (DC) pension plans have experienced substantial growth in the US, with almost 60 percent of covered workers now having these plans (Mitchell, Gordon, and Twinney 1997; U.S. DOL 2001). As more employees reach retirement with large DC pension accruals, they are increasingly allowed to receive their savings as a lump sum, rather than annuitizing the saving as under conventional defined benefit (DB) plans. The concern is that by taking their accumulated DC assets in a lump sum, participants face the risk of exhausting their pension assets before dying (Mitchell et al. 1997).

One way to protect against longevity risk is to purchase a life annuity. Economic models predict that risk-averse individuals with no bequest motives would strongly favor converting all their DC pension assets to private annuities; for example, Mitchell et al. (1999) show that age-65 retirees with access to an actuarially fair annuity market would be predicted to fully annuitize at age 65 . Further, that study estimated that people lacking access to an annuity market would be willing to forgo between 30 and 40 percent of their wealth at age 65, in order to purchase actuarially fair annuities. Later, Brown (2003) used the same approach to show how cross-group mortality differentials can influence life annuity insurance values. He found that annuities provide considerable longevity insurance to all groups, regardless of their race, ethnic group, or educational attainment, and even when annuity premiums are actuarially unfair, those facing high mortality (e.g. blacks with low education) would still value a life annuity.

These studies confirm the pioneering theoretical work of Yaari (1965) who showed that people with no bequest motives who face uncertain date of death would choose to fully 
annuitize. ${ }^{1}$ This approach, therefore, predicts that that there should be substantial growth in the US demand for life annuities, as more workers retire with large investments in DC plans. Yet this has not been the case to date. Thus Johnson et al. (2004) used 10 years of data from the Health and Retirement Study (HRS) ${ }^{2}$ to evaluate how persons age $55+$ disposed of their DC and Individual Retirement Account (IRA) funds. They reported that only four percent of workers with DC plans annuitized their assets when they retired, and only 13 percent of those who took their accumulations from IRAs converted the resources to private annuities. Further, the market for individual life annuity in the U.S. remains small, amounting to less than 10 percent of the size of the life insurance market (in 1999, Brown et al. 2001).

Several hypotheses have been offered to explain the low demand for private annuities, though considerable uncertainty about this puzzle remains. Some attribute the problem to adverse selection in annuity markets: for instance, only people with very low mortality might tend to purchase annuities, increasing the premium cost for people with average mortality prospects (e.g. Mitchell and McCarthy 2002). Nevertheless, although adverse selection does generate low rates of return in annuity contracts for persons of average mortality, annuity pricing seems to have little empirical impact on how consumers value life annuities (Brown 2003). Another explanation offered is that the elderly are over-annuitized in the form of Social Security, and thus they may not need to purchase additional annuitization to insure against longevity risk.

\footnotetext{
${ }^{1}$ Recently, Davidoff, Brown and Diamond (2003) have extended Yaari's model and derived the conditions for full annuitization to be optimal under a more general setting than that of the original model. Those authors show that when markets are complete, full annuitization is optimal even if some assumptions of Yaari's model are relaxed, such as additively separable utility. That paper further shows that the value of annuities lessens when annuity markets are incomplete, but some annuitization is still optimal as long as there is a positive premium for annuitizing wealth and conventional markets are complete.

${ }^{2}$ The Health and Retirement Study is a nationally representative study of the non-institutionalized population aged 51 and older and their spouses/partners (regardless of age). The HRS data contain detailed data on health, financial status, retirement and family support. Cohorts were interviewed in different waves from 1992 to 2002 (http://hrsonline.isr.umich.edu/).
} 
Empirical studies, however, tend to suggest that the elderly would be better off by purchasing additional private annuity contracts (Brown 2001a; Brown and Warshawsky 2001). Recently, Petrova (2003) used the HRS to evaluate whether perceived mortality influences the desire to purchase a life annuity and confirmed that private information on longevity has a strong influence on the decision to purchase a life annuity.

Information on health status is a key component of private information on longevity, and therefore it is a determinant of subjective survival probabilities (Hurd et al. 2001). Yet little is known about the relation between health status and the decision to purchase a life annuity. Earlier studies have investigated how uncertain health and therefore, uncertain medical expenses, affect consumption and saving decisions at older ages (e.g. Davis 1998; Hubbard, Skinner, and Zeldes 1995; Palumbo 1999). Our approach provides new evidence of the effect of health status on annuity decision-making, and it shows that the economic model which ignores health tends to overestimate both the level of desired annuitization and the insurance value of a life annuity. Our results suggest that retirees who face uncertain health would prefer to partially annuitize and maintain some assets in liquid form, so they can buffer the negative effect of unexpected out-ofpocket medical expenses on future consumption.

\section{Valuing Life Annuities}

In this section, we first discuss a general multiperiod model of annuity purchase with uncertain survival, and we then extend the approach to incorporate uncertain out-of-pocket medical expenses a well as uncertain survival. Next, we discuss parameterization of the models as well as data sources used to evaluate key outcomes. 


\section{Model 1: A Yaari-Type Model}

Our first approach extends the multiperiod model of Yaari's (1965) classical life-cycle approach with uncertain lifetimes, as developed by Brown (2003; 2001b) and Mitchell et al. (1999). We posit that, at retirement - say, age 65 - the individual decides how much of his starting wealth should be annuitized. This is a maximization problem: that is, given current and future conditions (e.g. interest rate and mortality distributions), the consumer maximizes the value function by selecting the amount of annuity which provides the largest discounted sum of expected future utility. The model posits that consumers are rational and understand the consequences of their choices for future consumption, even though the exact outcomes are probabilistic. That is, while one's date of death is uncertain, a forward-looking retiree can evaluate his mortality distribution based on his health status at the age of annuity purchase.

The consumer's problem is solved using backward recursion; first the terminal period problem is solved, and then we work backward to find the value function at age 65 . In the terminal period, $t=95$, the future value function is equal to 0 since death is certain by the next period $(t+1) .{ }^{3}$ Assuming no bequest motive, the retiree would maximize utility while consuming all remaining wealth, $W_{t}$; the period $t$ single immediate life annuity, $A_{t}$; and pre-existing real annuity (e.g. social security benefits) $S_{t}$ (Brown 2001b):

$$
V_{t}\left(c_{t}\right)=\max \left[u\left(c_{t}\right)\right]
$$

subject to the following constraints:

$$
\begin{array}{ll}
\text { s.t. } & W_{0} \text { given } \\
& W_{t} \geq 0 \quad \forall t \\
& W_{t+1}=\left(W_{t}-C_{t}+S_{t}+A_{t}\right)(1+r)
\end{array}
$$

\footnotetext{
${ }^{3}$ This is the maximum age for which we can estimate reliable parameters based on actual data. Using an older age for the terminal age does not affect our conclusions since the probability of surviving beyond age 95 is low.
} 
where $r$ is the interest rate. Knowing the optimal consumption decision in period $t$ allows one to find the optimal consumption decision that maximizes the value function in period $t-1$. The same logic is used subsequently in each previous period to choose the consumption that maximizes the Bellman equation:

$$
V_{t-1}=u\left(c_{t-1}\right)+\beta_{1} p_{t-1}\left[V_{t}\left(c_{t}\right)\right],
$$

where $\beta$ is the discount factor, and ${ }_{1} p_{t-1}$ is the probability of surviving from period $t-1$ to $t$ for an individual of health status $j$ at the age at annuity purchase. We approximate optimal consumption paths by making wealth discrete and testing a large number of values between arbitrary minimum and maximum values that are consistent with the initial conditions of the model.

We seek to learn both the optimal level of annuitization at age 65 and the value of a life annuity. Following Mitchell et al.(1999), we perform a counterfactual exercise with two scenarios. First, we estimate the value function assuming people have full access to the annuity market; in other words, we choose the optimal level of annuitization that maximizes the value function, ranging from 0 to full annuitization. Next, we estimate the value function in an alternative scenario where people have no access at all to the annuity market, and we ask how much additional starting wealth $\left(\mathrm{W}_{0}\right)$ they would have to receive to make them as well off, as in the first scenario with the annuitization option. The insurance value of a life-annuity is computed by comparing the two scenarios and computing the Annuity Equivalent Wealth measure (AEW), which indicates how much $\mathrm{W}_{0}$ in the second scenario needs to be increased to produce the same value function in both scenarios.

\section{Model 2: Out-of-Pocket Medical Expenses}

Uncertainty regarding medical expenses may offer a reason for retirees to maintain additional wealth instead of annuitizing all their assets, in which case, a model that ignores out- 
of-pocket medical expenses may not be fully descriptive of the world. We therefore next turn to an alternative version of the multiperiod model in which the retiree considers the effect of both uncertain future medical expenses and uncertain survival when choosing his optimal consumption path. Specifically, at the age of annuity purchase, we posit that the retiree has private information regarding his future health status. He uses this information to evaluate the distribution of future health transitions, although his exact future health outcomes remain probabilistic. Each period (year) from age 65 to 95 (or death), the individual learns whether he will incur out-of-pocket medical expenses. The probability of incurring out-of-pocket medical expenses posited to be a function of the retiree's health status, age, and sex. The model has the intuitive implication that people cannot precisely predict their future medical expenses, but they know their out-of-pocket medical expenses at each age, and they use this information when deciding about optimal future consumption.

The individual's problem in each period then has several possible outcomes. The expected value function is calculated by considering all possible combinations of health status and out-of-pocket medical expenses. The individual is posited to solve for consumption which maximizes utility for each possible path. At each period, the value function is the weighted sum of all solutions found, where the weights are the probabilities for each possible combination of health status and medical expenses:

$$
V_{t-1}\left(c_{t-1}, h_{t-1}, M_{t-1}\right)=\sum_{y=1}^{k} g_{y, t-1} \max \left[u\left(c_{t-1}, h_{t-1}, M_{t-1}\right)+\beta_{1} p_{t-1} V_{t}\left(c_{t}, h_{t}, M_{t}\right)\right]
$$

subject to the constraints:

$$
\begin{array}{ll}
\text { s.t. } & W_{0} \text { given } \\
& W_{t-1} \geq 0 \quad \forall t \\
& W_{t}=\left(W_{t-1}-C_{t-1}-M_{t-1}+S_{t-1}+A_{t-1}\right)(1+r), \quad \text { if } M_{t-1}>0
\end{array}
$$


where $\mathrm{h}_{\mathrm{t}-1}$ is health status at $t-1, \mathrm{M}_{\mathrm{t}-1}$ is period $t-1$ out-of-pocket medical expenses, and $\mathrm{g}_{\mathrm{t}-1}$ denotes the probabilities for the $k$ possible combinations of health status and medical expenses. Following earlier studies (e.g. Hubbard et al. 1995; Palumbo 1999), we assume that medical expenses are not a consumption good and that individuals cannot borrow against the future. Therefore, a retiree who incurs out-of-pocket medical expenses is constrained to consume only the resources that remain, after paying for medical care in each period. We also rely on the simplifying assumption that medical expenses in each period are uncorrelated with health status and mortality in the next period. ${ }^{4}$

The solution approach first involves choosing the optimal solution for terminal period and then we continue recursively to find the value function at the age 65 . In a fashion identical to that described above, the optimal consumption path is calculated for all annuitization options, and we then choose the one that gives the largest discounted sum of expected future utility. The AEW is then computed to estimate the insurance value of a life annuity in the context of uncertain out-of-pocket medical expenses. Results for both models are compared.

\section{Model Parameterization}

To implement the model we use the isoelastic utility function:

$$
U(c)=\frac{C^{1-\gamma}-1}{1-\gamma},
$$

where $\gamma$ is the coefficient of risk aversion (Brown 2001b; Hubbard et al. 1995). Since the third derivative of the isoelastic utility function is positive, thus it implicitly allows for precautionary savings that will arise out of uncertain out-of-pocket medical expenses in our second model

\footnotetext{
${ }^{4}$ Health status and mortality in period $t$ depend on health status in period $t-1$, and the probability of incurring medical costs is a function of health status in period $t-1$. For this reason, part of the correlation between medical expenses and health status or survival in period $t$ is indirectly accounted for in our model. Future work will explore alternative formulations.
} 
(Deaton 1992). Consistent with earlier studies (e.g. Hubbard et al. 1995), we assume a value for $\gamma$ of three in our main analysis, and we also present sensitivity analyses using alternative values for $\gamma$ of one and five. ${ }^{5}$ Further, we assume a value of three percent for the rate of time preference, $\beta$, and a real three percent rate of interest per year, consistent with earlier applications of the AEW measure (Brown 2001b; Mitchell et al. 1999; Petrova 2003).

We also must specify the probabilities of dying at each age, conditional on the health status at the age of annuity purchase (assumed to be 65). For example, suppose we are solving the models for an individual in good health at age 65 . We need to know his age-specific probabilities of dying at ages 65 to 95 , given he was in good health one to 30 years previously. The ideal dataset to estimate these would offer as many years of observation as the lifespans modeled. Unfortunately, no nationally representative panel data on long-term health and mortality have been collected. Consequently, we instead use a multi-state model (Palloni 2001; Schoen and Land 1979) to mimic the dependence of mortality on initial health states. This allows us to follow a hypothetical cohort from age 65 onward, and to calculate the probabilities of dying at each age, assuming persons at age 65 were in a specific state of health $j$. Each age-specific probability of dying is then posited to reflect health status as of the entry age of 65 .

The use of a multistate model requires the estimation of forces of decrement between states of health. We use the HRS from 1993 to 2000 to estimate these decrements, since the survey reports mortality and health changes every two years stayed in the same state of health for up to five years. Using cohort data is an improvement, compared to the cross sectional forms of

\footnotetext{
${ }^{5}$ Previous studies have suggested that risk aversion may vary across population subgroups; thus Halek and Eisenhauer (2001) find that risk aversion in the HRS increases with education and is higher among natives and non-Hispanics; also self-reported depressed individuals have 13 percent lower risk aversion than the average individual. In future research we will evaluate the sensitivity of results to the hypothesis that people in poor health have lower risk aversion than those in good health.
} 
the multistate model, since we can reasonably approximate some of the effects of duration on the forces of transition (Schoen 1988). The duration-specific probabilities are specified as a multinomial logit model of the following form:

$$
\ln \left(\frac{p_{j}}{p_{J}}\right)=\alpha_{j}+\beta_{j}^{A g e} x_{1}+\beta_{j}^{h} x_{2}+\beta_{j}^{h} x_{3} \quad j=1, . . J-1
$$

where $p_{j}$ is probability that an event $j$ (health transition or death) occurs; $p_{J}$ is the probability that a baseline event occurs; and $\mathrm{X}_{\mathrm{i}}$ are indicators of individual health status in earlier waves.

As noted by many, health is a multidimensional concept that can be measured in many different ways. In a previous study, we determined the best predictors of old-age mortality among several health indicators (Turra 2004). That model determined that functional status, smoking, and self-assessed health explain most of the deaths at ages 70+. Accordingly, for the present analysis, we derive results using three states of health based on functional status data: no functioning problems, IADL limitations, ${ }^{6}$ and ADL limitations. ${ }^{7}$ Table 1 summarizes estimates calculated from the mortality model described above. We show life expectancy at age 65 for both men and women, conditional on health status at age 65 . Not surprisingly, age-65 health differences have important implications for differences in life expectancy. For example, women with no functional limitations can expect to live 6.71 more years at age 65 than can women with ADL limitations. Among men, the difference of 5.7 years is smaller but still substantial.

\section{Table 1 here}

Assuming no loading and no taxes, the expected present value of the payment stream from a single immediate life annuity is given by Brown (2001b) as:

\footnotetext{
${ }^{6}$ Instrumental Activities of Daily Living. This state includes difficulties in performing at least one of the following activities: managing the money, making phone calls, preparing a hot meal, shopping for grocery.

${ }^{7}$ Activities of Daily Living. This state includes difficulties in performing at least one of the following activities: bathing/showering, dressing, eating and using the toilet, and getting in and out of bed.
} 


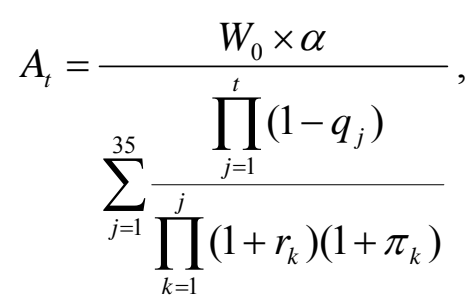

where $q_{j}$ is the age-specific probability of dying; $r_{k}$ is the real interest rate; and $\pi_{k}$ is the inflation rate. As mentioned above, the proportion of starting wealth $\left(\mathrm{W}_{0}\right)$ in single immediate life annuity, $\alpha$, indicates the optimal level of annuitization and is determined by the model.

To investigate the effects of adverse selection in the annuity market, we calculate optimal annuitization and AEW under two approaches to annuity pricing. A first set of estimates assumes that retirees have access to actuarially fairly priced annuities: ${ }^{8}$ in this case, we use the mortality distributions discussed above to calculate single immediate life annuity payments for someone in each health status. A second set of estimates assumes that all purchasers pay uniform prices; in this alternative case, we use the same mortality distribution for everyone to calculate the annuity payments irrespective of health status. The second scenario uses annuitant life table provided by the Society of Actuaries (SOA 1999).

Table 2 presents estimated expected discounted values of annuity payments per premium dollar. These estimates represent the case when everyone pays uniform pricing, as described above, and it also indicates how much annuity payouts vary across people in different health states. The results show that the value-per-premium dollar is always below one, regardless of sex and discount rate. Indeed, in an earlier study (Turra 2004), we found that annuitant mortality is slightly lower than mortality of healthy individuals in the population, which explains why the results in Table 2 are always below one. The values appear particularly low for men and retirees

\footnotetext{
${ }^{8}$ An actuarially fair premium is one in which the premium equals the present discounted value of expected annuity payments.
} 
with ADL limitations, between 0.65 and 0.70 . These estimates therefore imply that there would be significant adverse selection in the private annuity market, so that the decision to purchase a life annuity implies payouts well below the actuarially fair value, especially for retirees in poor health.

\section{Table 2 here}

Another central economic parameter is the amount of starting wealth invested in a preexisting real annuity; for instance this could include DB pension benefits and Social Security payments. The larger is the starting wealth in a pre-existing real annuity, the smaller will be the amount remaining that the retiree can use to purchase the life annuity. For many simulations, we assume that half of initial wealth is held in a pre-existing real annuity, a stylized description of the Social Security system (Mitchell and Moore 1998; Moore and Mitchell 2000). For sensitivity analyses, we also assume that the pre-existing real annuity is either 25 or 75 percent of total retirement wealth.

Our empirical approach handles out-of-pocket medical expenses as a percent of the retiree's pre-existing real annuity (pension or Social Security income), for two reasons. First, using relative rather than dollar values for out-of-pocket medical expenses avoids having to estimate dollar values for other model parameters, that is, all values are given in relative terms (e.g. relative to $\left.\mathrm{W}_{0}=100\right)$. Second, by making medical expenses a function of retirement income, this implicitly assumes that the amount that the elderly spend on health care depends on income levels, which is a reasonable way to represent the distribution of health care costs by socioeconomic group.

Estimating out-of-pocket medical expenses requires calculating: 1) the distribution of health status at each age; 2) the value of medical expenses (as a proportion of Social Security 
income); and 3) the probabilities of incurring medical expenses by age and health. To derive the distribution of health status by age, we use the multistate life table model discussed above to calculate the probability of being in each health state by age, conditional on the health state at the age of annuity purchase (assumed to be 65). Figure 1 summarizes the results for men, and the graphs show the distribution of health status by age among male survivors, given their functional status at age 65 . As expected, the distributions of health states are very different at early ages, but they become more similar at very old ages, as health deteriorates for all people regardless of their initial state of heath. ${ }^{9}$

Figure 1 here

Next, we calculate the value of out-of-pocket medical expenses as a proportion of Social Security income. We use estimates provided by RAND ${ }^{10}$ based on data from the Health and Retirement Study for the years 1998 and 2000. In the dataset, out-of-pocket medical expenses include expenditures not covered by health insurance in services such as hospital stays, nursing home stays, doctor visits, prescription drugs, dental care, home health care, outpatient surgery, and other services. In addition, we include total costs of premium for health insurance coverage. ${ }^{11}$ For each respondent aged 65 and older, we calculate the ratio of out-of-pocket medical expenses to Social Security income. For purposes of analytical tractability, we then create a discrete distribution of the ratios by dividing them into 11 categories of expenses, anchored at 0 and ranging to $\geq 300$ percent of Social Security income. Table 3 summarizes the distribution of observations in each of these categories, in the year 2000. As is clear, most of the individuals who incurred out-of-pocket expenses spent less than than 25 percent of their annual

\footnotetext{
${ }^{9}$ In general, results for women are similar, although the proportion of female survivors with functional limitations is higher than that of men (results available upon request).

${ }^{10}$ We use the 2004 RAND SSA-HRS datafile (http://www.rand.org/labor/aging/dataprod/\#randhrs).

${ }^{11}$ Total premiums includes premiums for employer-provided health insurance, private health insurance, long-term care insurance, Medicare through a Health Maintenance Organization, and Medigap.
} 
Social Security income. Nevertheless, about 5.5 percent of the elderly above age 65 did devote more 100 percent of their Social Security income to out-of-pocket medical expenses.

Table 3 here

To calculate the probability of incurring out-pocket-medical expenses in each category, we use a multinomial logit model controlling for health status two years earlier, age, and sex. Table 4 presents the results from fitting the logit model for five categories of medical expenses. ${ }^{12}$ The estimated coefficients give the partial effects of the explanatory variables on the log-odds of being in each category of medical expenses relative to the lowest category (of 0-25 percent of Social Security income). A positive coefficient indicates that the explanatory variable increases the probability of being in each category relative to the comparison category. It is apparent from Table 4 that the probability of incurring medical expenditures is significantly higher for women and persons in poor health status. The partial effects further indicate that age is significantly associated with the probability of incurring the highest category of medical costs $(300+$ percent of Social Security income).

Table 4 here

These probabilities of incurring out-of-pocket medical expenses are combined with the distributions of health status by age as described before, to compute the probability of each possible consumption path by age and health. Finally, to represent the value of out-of-pocket medical expenses and health, we use the median ratio in each category of out-of-pocket medical expenses (see Table 3).

\footnotetext{
${ }^{12}$ We present only results for five categories to make results clear; results for the omitted categories are consistent with those presented in Table 4.
} 


\section{Results}

Consider first the optimal annuitization and the annuity equivalent wealth (AEW) for people who face no uncertain medical expenses. For each state of health, they show the optimal choices under uniform pricing and actuarially fair risk pricing. We assume a pre-existing real annuity worth 50 percent of initial wealth, and three alternative degrees of risk aversion. Focusing on a risk aversion level of three, it appears that there are utility gains from purchasing a nominal annuity in Table 5, a finding consistent with previous empirical analyses (e.g. Brown 2003; Mitchell et al. 1999). Full annuitization is the optimal solution even when men and women lack access to an actuarially fair contract. Yet there is a much larger dispersion in the AEW values across population subgroups, as compared to earlier studies. Our figures vary between 1.17 and 1.85 , and they depend heavily on the interaction between health status and annuity pricing. In the case of women with ADL limitations, for example, AEW falls from 1.85 when annuities are actuarially fair, to only 1.17 under uniform pricing. In other words, adverse selection in annuities appears to impose high opportunity costs for people in poor health, and it also reduces considerably the insurance value of a nominal annuity.

\section{Table 5 here}

The effects of adverse selection are further evident at a risk aversion level of one. In this case, the results in Table 5 show that women with ADL limitations and men with IADL or ADL limitations will choose partial annuitization. For example, men with ADL limitations will invest only half of available wealth in private annuities. Not surprisingly, the insurance value of annuities also falls considerably: AEW is 1.02 and 1.04, respectively, for men and women with ADL limitations. 
Table 6 assumes that annuities provide consumers with a constant real payout stream; the results continue to ignore uncertain medical expenses. Compared to previous findings in the nominal annuity case, the actuarial pricing results indicate a slight increase in the utility gains from purchasing a real annuity. This pattern holds for people in good health, as well as for people in poor health with access to actuarially fair annuity premiums. Under uniform pricing, however, the opposite results obtain. Both men and women with ADL limitations would be worse off if they purchased a real rather than a fixed nominal annuity. This result is due to the fact that these persons have a low probability of surviving to the oldest ages. Since a fixed nominal annuity offers higher real payouts early on, as compared to a real annuity, the utility gains for the less healthy are higher in the first case. These findings suggest that insurers can mitigate the effects of adverse selection for people in poor health, and increase the demand for private annuities, by providing annuities that offer higher payments in earlier years of the contracts.

\section{Table 6 here}

We now shift attention to the results of our extended model to show how desired annuitization and AEW values change when people face both uncertain survival and uncertain out-of-pocket medical expenses. Table 7 reports the figures for each state of health and three values of pre-existing real annuity: 25, 50, and 75 percent of wealth. We focus on the case of a fixed nominal annuity under uniform pricing, and a risk aversion level of three.

\section{Table 7 here}

Here we see that both optimal annuitization and utility gains from purchasing a nominal annuity are lower when people face out-of-pocket medical expenses. In the case of a pre-existing real annuity worth 50 percent of wealth, we find that people would forgo less of their wealth to 
purchase a nominal annuity. When uncertain medical expenses are accounted for, the AEW values fall from 1.17 to 1.04 for men with ADL limitations, and from 1.27 to 1.19 for men with no functioning problems. Similar results are observed for women. These results suggest that AEW is overstated 5 to 11 percent ignoring out-of-pocket medical expenses. Not surprisingly, the largest differences are for people with functional limitations, since they have the highest probability of remaining in poor health and therefore have the highest risk of incurring out-ofpocket medical expenses over the life cycle.

The effect of uncertain out-of-pocket medical expenses is more evident when we compare optimal levels of annuitization. Previous studies have indicated that people in poor health rarely annuitize (Brown 2001b; Johnson et al. 2004). Indeed, our findings rationalize this empirical evidence, since because of precautionary motives, full annuitization is unlikely to be an optimal solution. In contrast to earlier studies and our simpler model, we now predict that all retirees, regardless of health status, will only partially annuitize at age 65. As expected, those in poorest health would be expected to convert the smallest amount of their wealth into an annuity. Table 6 shows that among men with ADL limitations, the optimal annuitization of additional wealth (conditional on Social Security being half of total wealth) is 19 percent, while among women in the same health status, the figure is 27 percent.

Finally, we also offer some sensitivity analysis for other parameters. Increasing the amount invested in Social Security and pension plans to 75 percent of wealth further reduces the optimal levels of annuitization and AEW values. Two factors explain this additional reduction. First, when more initial wealth is held as a pre-existing real annuity, the insurance value of additional annuitization is reduced. Second, as discussed earlier, out-of-pocket medical expenses are measured as a proportion of Social Security benefits. Therefore, increasing the value of pre- 
existing real annuity automatically increases the nominal value of out-of-pocket medical expenses, and therefore it produces more precautionary savings in our model. Although this is only one way to formulate the problem, it is illustrative in showing that private annuities can become worthless for people in poor health who are over-annuitized and face the risk of incurring large out-of-pocket medical expenses.

\section{Discussion}

We have examined how differences in health status can influence the decision to purchase a life annuity. Our main contribution has been to show that the insurance value of a life annuity may be smaller than that reported in prior studies. Our findings suggest that differences in health and anticipated health care expenses can help explain why many persons do not fully annuitize at retirement. While prior research suggested that an average person would forgo about 40 percent of his wealth to purchase a life annuity (Mitchell et al. 1999), these models indicate that this may not hold for the majority of the population, for two reasons. First, for someone with health problems, a life annuity priced using annuitant mortality rates implies expected payouts well below the actuarially fair value for that retiree. We provide evidence that adverse selection in annuities reduces the annuity equivalent wealth from values greater than 1.5 , to values close to 1.17 for people in poor health, and 1.28 for people in good health.

Previous studies have also ignored precautionary savings motivated by uncertain out-ofpocket medical expenses. Our stylized life cycle model with uncertain out-of-pocket medical expenses shows that annuities become less attractive to people facing such medical expenses. Caution is necessary when analyzing our results, since we compare optimal consumption paths for average consumers, and there may still be unexplained heterogeneity between people in different health states. Also, future research should incorporate correlation between medical 
expenses and future mortality as well as bequest motives. Finally, it may be useful to put our findings in context. Thus, regardless of health status and medical shocks, full annuitization would still be optimal, if annuity markets were truly complete and were both life and health contingent (Davidoff et al. 2003). Nevertheless, when both adverse selection and uncertain medical expenses are accounted for and annuity markets are incomplete, we show that annuity equivalent wealth values are fairly low for people in poor health, and about $25 \%$ higher for people in good health.

Some implications of our analysis are worth noting. First, earlier investigations have used the annuity equivalent wealth measures as explanatory variables in models predicting the probability of planning to annuitize (Brown 2001b; Petrova 2003). Although such models control for health status (Brown 2001b), our study indicates that they should account directly for health differentials in the AEW measures. Second, our findings also suggest that offering higher payouts for consumers in case of a medical shock can make annuities more attractive for many, and perhaps most, of the elderly. Future research should examine how insurers can fashion annuity contracts that better fit the needs of the older, perhaps unhealthy, population. Finally, this model predicts that most retirees would be made worse off by requiring full annuitization, if uniform pricing were involved. These results are important in the context of Social Security reforms proposing personal retirement accounts with mandatory annuitization. Indeed, mandatory annuitization should integrate risk classification providing actuarially fair annuities to people in different health states. 


\section{References}

Brown, J. R. 2001a. "Are the Elderly Really over-Annuitized? New Evidence on Life Insurance and Bequests". Pp. 91-126. In Themes in the Economics of Aging, ed. D. A. Wise. Chicago, IL: University of Chicago Press. . 2001b. "Private Pensions, Mortality Risk, and the Decision to Annuitize." Journal of Public Economics 82(1):29-62. 2003. "Redistribution and Insurance: Mandatory Annuitization with Mortality Heterogeneity." Journal of Risk and Insurance 70(1):17-41.

Brown, J. R., O. S. Mitchell, J. M. Poterba, and M. J. Warshawsky. 2001. The Role of Annuity Markets in Financing Retirement. Cambridge, MA: MIT Press.

Brown, J. R. and M. J. Warshawsky. 2001. "Longevity-Insured Retirement Distributions from Pension Plans: Market and Regulatory Issues". National Bureau of Economic Research Working Paper 8064.

Cogan, J. F. and O. S. Mitchell. 2003. "The Role of Economic Policy in Social Security Reform: Perspectives from the President Commission." Journal of Economic Perspective 17(2):149-172.

Collins, C. A. and D. R. Williams. 1999. "Segregation and Mortality: The Deadly Effects of Racism?" Sociological Forum 14(3):495-523.

Crimmins, E. M., M. D. Hayward, and Y. Saito. 1994. "Changing Mortality and Morbidity Rates and the HealthStatus and Life Expectancy of the Older Population." Demography 31(1):159-175.

Cutler, D. M. and E. Meara. 2001. "The Concentration of Medical Spending: An Update". Pp. 217-240. In Themes in the Economics of Aging, ed. D. A. Wise. Chicago, IL: University of Chicago Press.

Davidoff, T., J. R. Brown, and P. Diamond. 2003. "Annuities and Individual Welfare". National Bureau of Economic Research Working Paper 9714.

Davis, M. A. 1998. "The Health and Financial Decisions of the Elderly". Ph.D. Dissertation in the Department of Economics, University of Pennsylvania.

Deaton, A. 1992. Understanding Consumption. New York: Clarendon Press.

Halek, M. and J. G. Eisenhauer. 2001. "Demography of Risk Aversion." Journal of Risk and Insurance 68(1):1-24.

Hubbard, R. G., J. Skinner, and S. P. Zeldes. 1995. "Precautionary Saving and Social Insurance." Journal of Political Economy 103(2):360-399.

Hurd, M. D., D. McFadden, and A. Merrill. 2001. "Predictors of Mortality among the Elderly". Pp. 171-198. In Themes in the Economics of Aging, ed. D. A. Wise. Chicago, IL: University of Chicago Press.

Johnson, R. W., L. E. Burman, and D. I. Kobes. 2004. "Annuitized Wealth at Older Ages: Evidence from the Health and Retirement Study". Final Report to the Employee Benefits Security Administration, U.S. Department of Labor. Washington, DC: The Urban Institute.

Mitchell, O. S., M. S. Gordon, and M. M. Twinney. 1997. "Introduction: Assessing the Challenges to the Pension System". Pp. 1-11. In Positioning Pensions for the Twenty-First Century, ed. M. S. Gordon, O. S. Mitchell and M. M. Twinney. Philadelphia, PA: Pension Research Council University of Pennsylvania Press.

Mitchell, O. S. and D. McCarthy. 2002. "Estimating International Adverse Selection in Annuities." North American Actuarial Journal 6(4):38.

Mitchell, O. S. and J. F. Moore. 1998. "Can Americans Afford to Retire? New Evidence on Retirement Saving Adequacy." Journal of Risk and Insurance 65(3):371-400.

Mitchell, O. S., J. M. Poterba, M. J. Warshawsky, and J. R. Brown. 1999. "New Evidence on the Money's Worth of Individual Annuities." American Economic Review 89(5):1299-1318.

Moore, J. F. and O. S. Mitchell. 2000. "Projected Retirement Wealth and Savings Adequacy". Pp. 68-94. In Forecasting Retirement Needs and Retirement Wealth, ed. O. S. Mitchell, P. B. Hammond and A. M. Rappaport. Philadelphia: University of Pennsylvania Press.

Palloni, A. 2001. "Increment-Decrement Life Tables". Pp. 256-272. In Demography : Measuring and Modeling Population Processes, ed. S. H. Preston, P. Heuveline and M. Guillot. Malden, MA: Blackwell Publishers.

Palumbo, M. G. 1999. "Uncertain Medical Expenses and Precautionary Saving near the End of the Life Cycle." Review of Economic Studies 66(2):395-421.

Petrova, P. 2003. "The Annuity Puzzle Gets Bigger". Working Paper, January 2003: Boston College.

Schoen, R. 1988. Modeling Multigroup Populations. Plenum Series on Demographic Methods and Population Analysis. New York: Plenum Press.

Schoen, R. and K. C. Land. 1979. "General Algorithm for Estimating a Markov-Generated Increment-Decrement Life Table with Applications to Marital-Status Patterns." Journal of the American Statistical Association 74(368):761-776. 
Society of Actuaries. 1999. "Exposure Draft. The Rp-2000 Mortality Tables". Working Paper. Schaumburg, IL: Society of Actuaries.

Turra, C. M. 2004. "Living and Dying at Older Ages: Essays on the Hispanic Mortality Paradox and the Annuity Puzzle in the U.S." Doctoral Dissertation in the Graduate Group in Demography, University of Pennsylvania.

United States Department of Labor (USDOL) Pension and Welfare Benefits Administration. Abstract of 1998 Form 5500 Annual Reports. Private Pension Plan Bulletin No. 11, Winter 2001. Washington, DC: USGPO, 2001.

Yaari, M. E. 1965. "Uncertain Lifetime, Life-Insurance, and the Theory of the Consumer." Review of Economic Studies 32:137-150. 
Table 1 Life Expectancy at Age 65, HRS (1993-2000)

\begin{tabular}{lcc}
\hline & Women & Men \\
\hline No Functioning Problems & 21.04 & 16.78 \\
IADL Limitations & 18.89 & 14.20 \\
ADL Limitations & 14.33 & 11.06 \\
\hline
\end{tabular}

Source: Author's calculations as described in the text.

Table 2 Annuity values per premium dollar, fixed immediate real annuity purchased at age 65, before-tax calculations

\begin{tabular}{cccc}
\hline & \multicolumn{3}{c}{ Health at the age of annuity purchase } \\
\cline { 2 - 4 } & $\begin{array}{c}\text { No Functioning } \\
\text { Problems }\end{array}$ & $\begin{array}{c}\text { IADL } \\
\text { Limitations }\end{array}$ & $\begin{array}{c}\text { ADL } \\
\text { Limitations }\end{array}$ \\
$\begin{array}{c}\text { Sex \& } \\
\text { Discount Rate }\end{array}$ & & & \\
\hline Men & & & \\
$3 \%$ & 0.89 & 0.76 & 0.60 \\
$5 \%$ & 0.91 & 0.79 & 0.63 \\
$7 \%$ & & 0.81 & 0.66 \\
Women & & & \\
$3 \%$ & 0.97 & 0.88 & 0.69 \\
$5 \%$ & 0.98 & 0.90 & 0.71 \\
$7 \%$ & 0.98 & 0.91 & 0.74 \\
\hline
\end{tabular}

Notes: Each entry shows the expected present discounted value of the annuity payouts per dollar of annuity premium. All calculations assume premium costs are calculated based on the Annuitant Mortality Life Table (SOA 1999).

Assuming no loads as per Mitchell et al. (1999). 
Table 3 Distribution of Out-of-Pocket Medical Expenses (as a proportion of Social Security Income)

\begin{tabular}{ccc}
\hline $\begin{array}{c}\text { Categories } \\
\text { \% of Social } \\
\text { Secuirty Income) }\end{array}$ & $\begin{array}{c}\text { Median } \\
\text { Value }\end{array}$ & $\begin{array}{c}\text { Frequency } \\
(\%)\end{array}$ \\
\hline 0 & & \\
$0-25$ & 0 & 20.12 \\
$25-50$ & 11.79 & 48.87 \\
$50-75$ & 43.53 & 16.20 \\
$75-100$ & 68.58 & 6.52 \\
$100-125$ & 96.04 & 2.76 \\
$125-150$ & 122.25 & 1.48 \\
$150-175$ & 139.19 & 0.92 \\
$175-200$ & 168.02 & 0.64 \\
$200-300$ & 194.13 & 0.44 \\
$300+$ & 268.32 & 0.81 \\
& 489.34 & 1.25 \\
\hline
\end{tabular}

Source: HRS 2000 
Table 4 Maximum Likelihood Estimation Results of the Probability of Incurring Out-of-Pocket Medical Expenses Between 1998 and 2000, Ages 65 and Older

\begin{tabular}{|c|c|c|c|c|c|}
\hline Condition in 1998 & $\log (\mathrm{L} 2 / \mathrm{L} 1)$ & $\log (\mathrm{L} 4 / \mathrm{L} 1)$ & $\log (\mathrm{L} 6 / \mathrm{L} 1)$ & $\log (\mathrm{L} 8 / \mathrm{L} 1)$ & $\log (\mathrm{L} 10 / \mathrm{L} 1)$ \\
\hline Constant & $\begin{array}{l}-2.024 * * \\
(0.335)\end{array}$ & $\begin{array}{l}-4.414 * * \\
(0.730)\end{array}$ & $\begin{array}{l}-4.556^{* *} \\
(1.279)\end{array}$ & $\begin{array}{l}-8.656 \text { ** } \\
(1.905)\end{array}$ & $\begin{array}{l}-10.938 * * \\
(1.079)\end{array}$ \\
\hline Age & $\begin{array}{r}0.005 \\
(0.004)\end{array}$ & $\begin{array}{r}0.002 \\
(0.010)\end{array}$ & $\begin{array}{r}-0.016 \\
(0.017)\end{array}$ & $\begin{array}{r}0.046 \\
(0.025)\end{array}$ & $\begin{array}{l}0.073 * \\
(0.013)\end{array}$ \\
\hline Sex (Female) & $\begin{array}{l}0.272 \text { ** } \\
(0.061)\end{array}$ & $\begin{array}{l}0.644 * * \\
(0.145)\end{array}$ & $\begin{array}{l}0.835 \text { ** } \\
(0.256)\end{array}$ & $\begin{array}{r}-0.030 \\
(0.372)\end{array}$ & $\begin{array}{l}0.455 * * \\
(0.229)\end{array}$ \\
\hline \multicolumn{6}{|l|}{ Health Status ${ }^{a}$} \\
\hline IADL Limitations & $\begin{array}{l}0.251 \text { ** } \\
(0.065)\end{array}$ & $\begin{array}{c}0.391 \\
(0.154)\end{array}$ & $\begin{array}{r}0.441 \\
(0.256)\end{array}$ & $\begin{array}{r}-0.015 \\
(0.461)\end{array}$ & $\begin{array}{l}0.932 \text { ** } \\
(0.288)\end{array}$ \\
\hline ADL Limitations & $\begin{array}{l}0.239 \text { ** } \\
(0.089)\end{array}$ & $\begin{array}{l}0.935 \text { ** } \\
(0.174)\end{array}$ & $\begin{array}{l}0.845^{* *} \\
(0.301)\end{array}$ & $\begin{array}{c}1.010 \\
(0.446)\end{array}$ & $\begin{array}{l}1.736 \text { ** } \\
(0.291)\end{array}$ \\
\hline
\end{tabular}

Log-Likelihhod Function $=-13,110$

Sample Size $=9,038$

Source: HRS (1998, 2000)

Notes: Categories of Medical Expenses ( $\%$ of Social Security Income): L1= 0-25 percent; L2= 25-50 percent; L4= 75-100 percent;

L6 $=125-150$ percent; $L 8=175-200$ percent; $\mathrm{L} 10=300+$ percent. Standard errors in parantheses. $* \mathrm{p}<.05 ; * * \mathrm{p}<.01$

${ }^{\mathrm{a}}$ No Functioning Problems is used as the reference category. 
Table 5 Annuity Equivalent Value and Optimal Annuitization, Model 1, Fixed Nominal Annuity (Inflation $=3.2 \%$ )

\begin{tabular}{|c|c|c|c|c|c|c|}
\hline & \multicolumn{6}{|c|}{ Pre-Existing Real Annuity Worth $50 \%$ of Wealth } \\
\hline & \multicolumn{2}{|c|}{$\mathrm{CRRA}=1$} & \multicolumn{2}{|c|}{$\mathrm{CRRA}=3$} & \multicolumn{2}{|c|}{$\mathrm{CRRA}=5$} \\
\hline & $\begin{array}{l}\text { Annuity } \\
\text { Equivalent } \\
\text { Wealth } \\
\end{array}$ & $\begin{array}{c}\text { Optimal } \\
\text { Additional } \\
\text { Annuitization } \\
\text { (\% Wealth) }\end{array}$ & $\begin{array}{l}\text { Annuity } \\
\text { Equivalent } \\
\text { Wealth } \\
\end{array}$ & $\begin{array}{c}\text { Optimal } \\
\text { Additional } \\
\text { Annuitization } \\
(\% \text { Wealth }) \\
\end{array}$ & $\begin{array}{c}\text { Annuity } \\
\text { Equivalent } \\
\text { Wealth } \\
\end{array}$ & $\begin{array}{c}\text { Optimal } \\
\text { Additional } \\
\text { Annuitization } \\
\text { (\% Wealth) }\end{array}$ \\
\hline \multicolumn{7}{|l|}{ Women } \\
\hline \multicolumn{7}{|l|}{ No Functioning Problems } \\
\hline Actuarially Fair Premium & 1.172 & 50 & 1.244 & 50 & 1.245 & 50 \\
\hline Uniform Pricing & 1.152 & 50 & 1.222 & 50 & 1.224 & 50 \\
\hline \multicolumn{7}{|l|}{ IADL Limitations } \\
\hline Actuarially Fair Premium & 1.241 & 50 & 1.340 & 50 & 1.359 & 50 \\
\hline Uniform Pricing & 1.122 & 50 & 1.220 & 50 & 1.229 & 50 \\
\hline \multicolumn{7}{|l|}{ ADL Limitations } \\
\hline Actuarially Fair Premium & 1.435 & 50 & 1.629 & 50 & 1.675 & 50 \\
\hline Uniform Pricing & 1.043 & 39 & 1.170 & 50 & 1.230 & 50 \\
\hline \multicolumn{7}{|l|}{ Men } \\
\hline \multicolumn{7}{|l|}{ No Functioning Problems } \\
\hline Actuarially Fair Premium & 1.261 & 50 & 1.395 & 50 & 1.437 & 50 \\
\hline Uniform Pricing & 1.156 & 50 & 1.277 & 50 & 1.366 & 50 \\
\hline \multicolumn{7}{|l|}{ IADL Limitations } \\
\hline Actuarially Fair Premium & 1.379 & 50 & 1.570 & 50 & 1.639 & 50 \\
\hline Uniform Pricing & 1.096 & 46 & 1.248 & 50 & 1.311 & 50 \\
\hline \multicolumn{7}{|l|}{ ADL Limitations } \\
\hline Actuarially Fair Premium & 1.550 & 50 & 1.852 & 50 & 1.980 & 50 \\
\hline Uniform Pricing & 1.022 & 26 & 1.167 & 50 & 1.263 & 50 \\
\hline
\end{tabular}

Source: Author's calculations as described in the text. 
Table 6 Annuity Equivalent Value and Optimal Annuitization, Model 1, Real Annuity

\begin{tabular}{|c|c|c|c|c|c|c|}
\hline & \multicolumn{6}{|c|}{ Pre-Existing Real Annuity Worth $50 \%$ of Wealth } \\
\hline & \multicolumn{2}{|c|}{$\mathrm{CRRA}=1$} & \multicolumn{2}{|c|}{$\mathrm{CRRA}=3$} & \multicolumn{2}{|c|}{$\mathrm{CRRA}=5$} \\
\hline & $\begin{array}{c}\text { Annuity } \\
\text { Equivalent } \\
\text { Wealth } \\
\end{array}$ & $\begin{array}{c}\text { Optimal } \\
\text { Additional } \\
\text { Annuitization } \\
(\% \text { Wealth }) \\
\end{array}$ & $\begin{array}{c}\text { Annuity } \\
\text { Equivalent } \\
\text { Wealth } \\
\end{array}$ & $\begin{array}{c}\text { Optimal } \\
\text { Additional } \\
\text { Annuitization } \\
(\% \text { Wealth }) \\
\end{array}$ & $\begin{array}{c}\text { Annuity } \\
\text { Equivalent } \\
\text { Wealth } \\
\end{array}$ & $\begin{array}{c}\text { Optimal } \\
\text { Additional } \\
\text { Annuitization } \\
\text { (\% Wealth) }\end{array}$ \\
\hline \multicolumn{7}{|l|}{ Women } \\
\hline \multicolumn{7}{|l|}{ No Functioning Problems } \\
\hline Actuarially Fair Premium & 1.187 & 50 & 1.290 & 50 & 1.322 & 50 \\
\hline Uniform Pricing & 1.154 & 50 & 1.255 & 50 & 1.285 & 50 \\
\hline \multicolumn{7}{|l|}{ IADL Limitations } \\
\hline Actuarially Fair Premium & 1.255 & 50 & 1.387 & 50 & 1.439 & 50 \\
\hline Uniform Pricing & 1.110 & 44 & 1.230 & 50 & 1.270 & 50 \\
\hline \multicolumn{7}{|l|}{ ADL Limitations } \\
\hline Actuarially Fair Premium & 1.451 & 50 & 1.681 & 50 & 1.776 & 50 \\
\hline Uniform Pricing & 1.030 & 25 & 1.151 & 42 & 1.220 & 44 \\
\hline \multicolumn{7}{|l|}{ Men } \\
\hline \multicolumn{7}{|l|}{ No Functioning Problems } \\
\hline Actuarially Fair Premium & 1.273 & 50 & 1.441 & 50 & 1.510 & 50 \\
\hline Uniform Pricing & 1.139 & 46 & 1.280 & 50 & 1.359 & 50 \\
\hline \multicolumn{7}{|l|}{ IADL Limitations } \\
\hline Actuarially Fair Premium & 1.393 & 50 & 1.616 & 50 & 1.727 & 50 \\
\hline Uniform Pricing & 1.075 & 35 & 1.228 & 45 & 1.309 & 50 \\
\hline \multicolumn{7}{|l|}{ ADL Limitations } \\
\hline Actuarially Fair Premium & 1.563 & 50 & 1.903 & 50 & 2.073 & 50 \\
\hline Uniform Pricing & 1.011 & 16 & 1.140 & 38 & 1.233 & 43 \\
\hline
\end{tabular}


Table 7 Annuity Equivalent Value and Optimal Annuitization Under Uniform Pricing, Results for Both Models, Fixed Nomimal Annuity

\begin{tabular}{|c|c|c|c|c|c|c|}
\hline & \multicolumn{2}{|c|}{$\begin{array}{l}\text { Pre-Existing Real Annuity } \\
\text { Worth } \mathbf{2 5 \%} \text { of Wealth }\end{array}$} & \multicolumn{2}{|c|}{$\begin{array}{l}\text { Pre-Existing Real Annuity } \\
\text { Worth } \mathbf{5 0 \%} \text { of Wealth }\end{array}$} & \multicolumn{2}{|c|}{$\begin{array}{c}\text { Pre-Existing Real Annuity } \\
\text { Worth } 75 \% \text { of Wealth }\end{array}$} \\
\hline & $\begin{array}{c}\text { Annuity } \\
\text { Equivalent } \\
\text { Wealth }\end{array}$ & $\begin{array}{c}\text { Optimal } \\
\text { Additional } \\
\text { Annuitization } \\
\text { (\% Wealth) } \\
\end{array}$ & $\begin{array}{c}\text { Annuity } \\
\text { Equivalent } \\
\text { Wealth } \\
\end{array}$ & $\begin{array}{c}\text { Optimal } \\
\text { Additional } \\
\text { Annuitization } \\
\text { (\% Wealth) }\end{array}$ & $\begin{array}{c}\text { Annuity } \\
\text { Equivalent } \\
\text { Wealth } \\
\end{array}$ & $\begin{array}{c}\text { Optimal } \\
\text { Additional } \\
\text { Annuitization } \\
\text { (\% Wealth) }\end{array}$ \\
\hline \multicolumn{7}{|l|}{ Women } \\
\hline \multicolumn{7}{|l|}{ No Functioning Problems } \\
\hline Model 1: Uncertain Survival & 1.229 & 75 & 1.222 & 50 & 1.195 & 25 \\
\hline Model 2: Uncertain Survival w/ oop Med.Costs & 1.221 & 75 & 1.160 & 46 & 1.066 & 16 \\
\hline \multicolumn{7}{|l|}{ IADL Limitations } \\
\hline Model 1: Uncertain Survival & 1.229 & 75 & 1.220 & 50 & 1.220 & 25 \\
\hline Model 2: Uncertain Survival w/ oop Med.Costs & 1.207 & 75 & 1.129 & 36 & 1.017 & 13 \\
\hline \multicolumn{7}{|l|}{ ADL Limitations } \\
\hline Model 1: Uncertain Survival & 1.221 & 75 & 1.170 & 50 & 1.068 & 25 \\
\hline Model 2: Uncertain Survival w/ oop Med.Costs & 1.183 & 67 & 1.051 & 27 & 0.985 & -3 \\
\hline \multicolumn{7}{|l|}{ Men } \\
\hline \multicolumn{7}{|l|}{ No Functioning Problems } \\
\hline Model 1: Uncertain Survival & 1.332 & 75 & 1.277 & 50 & 1.193 & 25 \\
\hline Model 2: Uncertain Survival w/ oop Med.Costs & 1.301 & 75 & 1.196 & 36 & 1.061 & 15 \\
\hline \multicolumn{7}{|l|}{ IADL Limitations } \\
\hline Model 1: Uncertain Survival & 1.309 & 75 & 1.248 & 50 & 1.139 & 25 \\
\hline Model 2: Uncertain Survival w/ oop Med.Costs & 1.282 & 69 & 1.135 & 31 & 1.019 & 12 \\
\hline \multicolumn{7}{|l|}{ ADL Limitations } \\
\hline Model 1: Uncertain Survival & 1.276 & 75 & 1.167 & 50 & 1.046 & 18 \\
\hline Model 2: Uncertain Survival w/ oop Med.Costs & 1.230 & 64 & 1.042 & 19 & 0.987 & -3 \\
\hline
\end{tabular}


Figure 1 Distribution of Health Status by Age, conditional on Health Status at age 65, Men
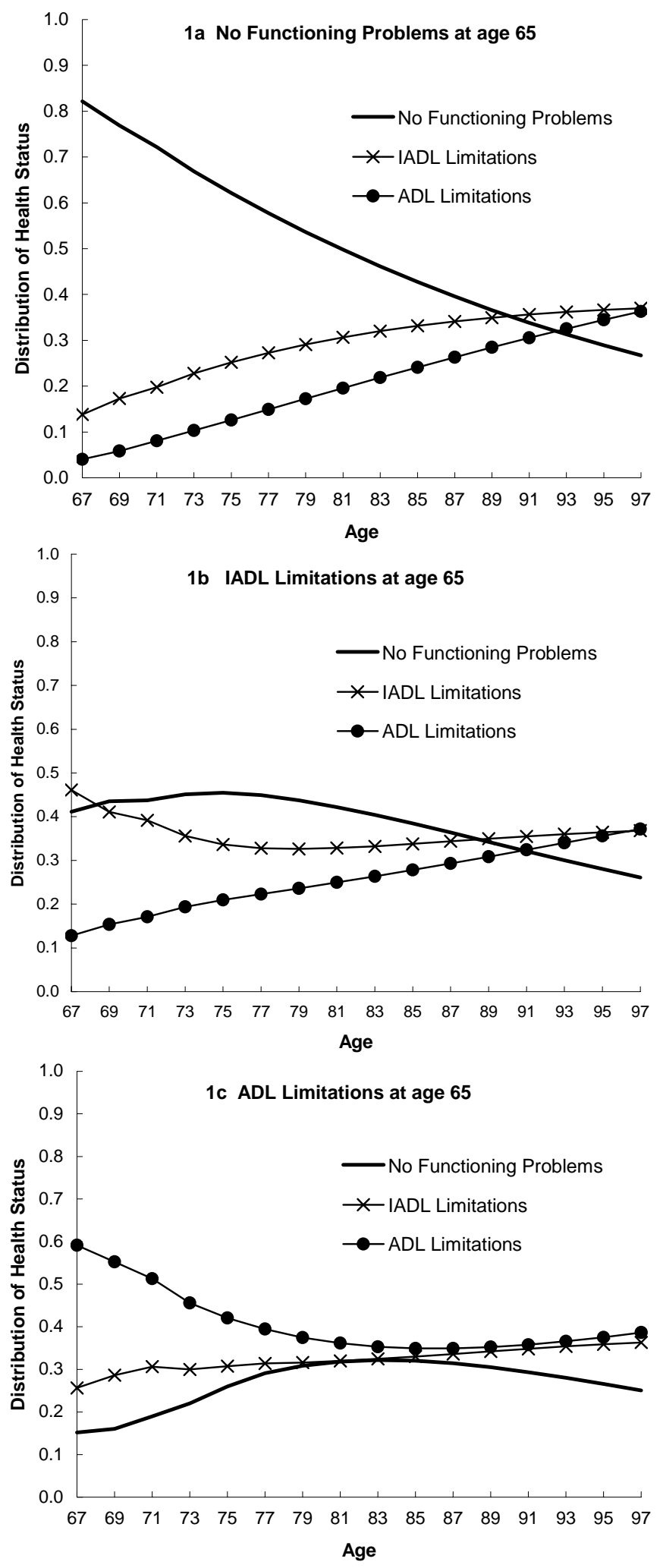

Source: HRS (1993-2000) 